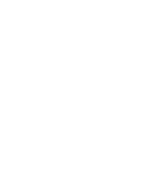

\section{REVIEWS Further}

Click here for quick links to Annual Reviews content online, including:

- Other articles in this volume

- Top cited articles

- Top downloaded articles

- Our comprehensive search

\title{
The Reorganization of the Sensory World
}

\author{
Thomas Porcello, ${ }^{1}$ Louise Meintjes, ${ }^{2}$ \\ Ana Maria Ochoa, ${ }^{3}$ and David W. Samuels ${ }^{4}$ \\ ${ }^{1}$ Department of Anthropology, Vassar College, Poughkeepsie, New York 12604; \\ email: thporcello@vassar.edu \\ ${ }^{2}$ Departments of Music and Cultural Anthropology, Duke University, Durham, \\ North Carolina 27708-0665; email: meintjes@duke.edu \\ ${ }^{3}$ Department of Music, Columbia University, New York, NY 10027; \\ email: ao2110@columbia.edu \\ ${ }^{4}$ Department of Music, New York University, New York, NY 10003; \\ email: dws2004@nyu.edu
}

Annu. Rev. Anthropol. 2010. 39:51-66

First published online as a Review in Advance on June 14, 2010

The Annual Review of Antbropology is online at anthro.annualreviews.org

This article's doi:

10.1146/annurev.anthro.012809.105042

Copyright (c) 2010 by Annual Reviews.

All rights reserved

0084-6570/10/1021-0051\$20.00

\section{Key Words}

senses, mediation, discourse, multisensory, materiality

\begin{abstract}
Although anthropological and critical social theory have a long interest in sensory experience, work on the senses has intensified within the past 20 years. This article traces three sensory genealogies within anthropology: the work of Ong and McLuhan as critiqued and advanced by David Howes and the Concordia Project; phenomenological studies as advanced by Paul Stoller; and a focus on materialities as advanced by Nadia Seremetakis. Studies of individual senses, which we survey, led to calls for a more integrated approach to the senses, both within anthropology and from cinema and media studies. In various ways, the senses are constituted by their imbrication in mediated cultural practices, whether mediated by technology, discourse, or local epistemologies. We argue that integrating language and discourse into the study of the senses along with new media insights more fully articulates the significance of body-sensorial knowledge.
\end{abstract}




\section{INTRODUCTION}

Anthropological and critical social theory have a long but spotty history of interest in sensory experience. Franz Boas (1901), for example, noted that, "it has been observed by many travelers that the senses of primitive man are remarkably well trained" (p. 4). Boas turned away from the senses, however, to focus on the importance of distinct forms of cultural association through which new sensory experiences were given meaningful import in different cultural formations. Karl Marx wrote in "Private Property and Communism" (1988 [1844], p. 109) that "the forming of the five senses is a labor of the entire history of the world down to the present," but he never followed through on the implications of this insight. Similarly, in The Raw and the Cooked, Claude Lévi-Strauss (1969) wrote a "Fugue for the Five Senses" as part of his analysis of Ge mythology. Even though the general tenor of his work remained highly abstract, two things are crucial in his analysis: The senses are not understood in isolation; rather each sense "suggests other sensory coding systems" (p. 153). Furthermore, the senses act as key articulators between the binary pairs of his structural analysis. Along with Marx and Lévi-Strauss, Sigmund Freud is sometimes cited as an important precursor to an anthropology of the senses (see Howes 2003, pp. xiv-xx).

More recently, numerous anthropologists have made a concerted effort to address the senses as a central object of research (Classen 2005; Classen et al. 1994; Howes 1991, 2003, 2005; Jackson 1989, 1996; Seremetakis 1994; Stoller 1989, 1997; Taussig 1993, 2009). Their work grapples with the materiality and sociality of the senses as culturally constituted and constitutes the sensorium as a cultural entity. But a reorganization of modes of thinking about the senses does not come solely from this work. Scholarship on technology and mediation that has prompted a reconsideration of the senses in modernity and postmodernity; the anthropology of ritual that addresses its aesthetic, performative, and perceptual dimensions; attention to the ethnopoetic and performative aspects of expressive culture; the turn to the body as a site of knowledge; and the recasting of the natureculture divide in recent anthropological work have all played a role in rethinking the place of the senses in anthropological scholarship.

We begin by tracing three genealogies that in tandem articulated an anthropology of the senses in the late 1980s, drawing on earlier considerations of the importance of the senses for understanding cultural experience. As the field then developed through explorations of individual senses, we discuss research on taste, smell, touch, hearing, and vision, with an eye toward the work of anthropologists as well as an interdisciplinary literature in which anthropology has been a participant. We discuss subsequent calls for an integrative approach to the senses; although this call has come from within anthropology, it has also followed from other disciplines' explorations of relationships among the body, technology, and mediation. We conclude with what we see as an avenue of further development for an anthropology of the senses. While in its initial stages, the anthropology of the senses repeatedly cast itself as a critical response to discourse-centered approaches to culture. We believe that creating an opening to allow language and discourse into an approach to the senses adds important insights to understanding the cultural constitution of the sensorium. Thus we echo the call for an integrative approach to the senses that considers the work of scholars of mediation and technology, but we argue that the turn away from incorporating language and discourse into the anthropology of the senses forecloses potentially productive connections between language and the senses. We propose that the most productive of these connections can derive from work on aesthetic practices that mobilize both language and expressive-sensorial practices.

\section{THE SENSES IN ANTHROPOLOGY: THREE GENEALOGIES}

Anthropological work focused on the senses is founded on the insistence that the senses are not 
merely a biological ground on which cultural meanings are constructed. Rather, the senses are always already fully cultural, and "sensory perception is a cultural as well as physical act" (Classen 1997, p. 401). Responding to the static and textual nature of previous anthropological interpretations of cultural experience, anthropologists working on the senses since the 1980s, sharing some ground with the field of performance studies, have considered various ways of framing, researching, and writing about experience, emphasizing the lived and emergent nature of the senses, the cultural embeddedness of sensory experience, and the historical and political relations between sensory orders and social orders.

One impetus for the emergence of an anthropology of the senses came out of a growing dissatisfaction with anthropologists' analyses of the role of ritual and ceremony in everyday life (e.g., Stoller 1989). Examining aesthetics and performance in the constitution of the social, scholars within the anthropology of religion responded to two growing difficulties with anthropological interpretations of ritual in the late 1970s (Basso 1985, Bauman 1977). The first was the perceived overemphasis of functionalism on equilibrium, represented most clearly by Victor Turner's focus on conflict as social disruption that is reparable through ritual performance (Crapanzano 1992). The second was the sense that structuralism's textuality neglected the sensory processes of lived, encultured experiences of myth and ritual (Feld 1990 [1982]). Despite these critiques, Turner and LéviStrauss remain important precursors for work in the anthropology of the body and senses, especially in ethnographies of religion and healing. In fact, their modes of analysis prefigure types of relations developed as a critical creative response to their work by subsequent anthropologists (Farquhar 2002; Lambek 2003; Lambek \& Strathern 1998; Viveiros de Castro 1992, 2004).

Another thread linking anthropological work on the senses has been a critique of western ocularcentrism that has created fertile points of cross-disciplinary contact. Challeng- ing the philosophical and theological histories that posited sight as the highest of the sensory faculties, as the privileged means of coming to know God, or as the sense most closely linked to epistemological certainty as well as rationality (Jay 1993, Synnott 1991), anthropologists worked to document and analyze other cultural organizations of sensory knowledge, experience, and configuration. Some of these studies challenged ocularcentrism by focusing on other senses, leading to books and articles focused solely on one sense; others sought to challenge presuppositions of the senses as rigidly separate phenomena or of the sensorium as necessarily constituted of only five senses and of these particular senses (Geurts 2002, Howes 2009). Of the three genealogies that lie behind much of this work, one comes out of communication, another originates in phenomenology, and a third concerns materiality. We focus on three scholars whose work particularly strongly embodies these genealogies. Because several other excellent works address the emergence of the anthropology of the senses (Herzfeld 2001, Howes 2003), what follows is not intended to be comprehensive, but illustrative of what we see as the lines of thinking that have had the most impact on anthropological research.

\section{Communication}

Howes (1991, 2003, 2005) links an anthropology of the senses to a critical engagement with the media insights of Ong and McLuhan. Although he notes precursors in Marx and Freud, Howes argues that it was not until Ong's and McLuhan's discussions of media's agency in shaping forms of social being that an understanding of the sensorium as historically and socially constituted in specific ways became possible. Howes also credits, to a lesser extent, Carpenter's work in cross-cultural aesthetics (1973), and Leavitt \& Hart (1990) have emphasized the work of Goody (1977) as well.

For Howes (2003), the sensorium is "the most fundamental domain of cultural expression, the medium through which all the values and practices of society are enacted" (p. 1). 
Relations between the senses "are also social relations" (p. 55). Howes argues (2005) that the "ratios" of the senses- the relationships between vision, hearing, taste, touch, and smellare socially constituted (p. 10) and that cultural productions constitute social relations through sensuous experience (p. 3). He critiques the lack of nuance in McLuhan's idea of ratios as technologically determined and dominated by one particular sense at a time. His support of the senses as sources of cultural experience and anthropological knowledge is coupled with a distrust of the antisensual nature of the discipline's turn to discourse (2005) and "the detour represented by the rise of the textual model of cultural analysis in the 1970s" (2003, p. xiv).

The collaborative and synthetic work of Howes and his colleagues at Concordia University, Classen and Synott, has substantially raised the presence of the senses within anthropology, leading to conferences, papers, a special edition of Anthropologie et Sociétés (1990), as well as the establishment of the journal, The Senses of Society, a book series, Sensory Formations, and a series of readers about the senses. This work has drawn together European and North American cross-disciplinary research that is historical and ethnographic, and it has engaged cultural and media studies scholars in a dialogue with humanists and social scientists. Much of their work can be found at http://alcor.concordia.ca/ senses/.

\section{Phenomenology}

Stoller originally set out to conduct research about the ritual language of the Songhay of Niger in 1976/1977. Through years of field research and an eventual immersion into the worlds of sorcery and possession, he turned from linguistics to a focus on knowledge held in multisensory experience. He drew especially on Merleau-Ponty's critique of the Cartesian mind/body split, arguing that perceptual knowledge played a crucial role in the ways in which the senses mediate the worlds of the material, social, and spiritual. In integrating perceptual knowledge into his analysis, Stoller lent equivalent epistemic weight to local material, social, and spiritual truths (Stoller 1989, 1997).

Stoller calls for a new kind of scholarship that comprehensively sensorializes the fieldwork and ethnographic practices of cultural anthropologists. He advocates for anthropologists to consider the sensory worlds of others (not only their language), but also to attend to the full range of their own senses, not just to sight, which he considers to be the "privileged sense of the West" (Stoller 1989, p. 5). "Sensuous scholarship," however, is not only about attending to questions of voice and taking critical account of the senses: These are a means by which to get at the "phenomenology of the fieldwork encounter" (Stoller 1997, p. 43) and the politics of representation, and thereby to recognize "the increasingly political implications of our works" (p. 34).

\section{Materiality}

Another stream contributing to the anthropology of the senses, most notably in the work of Seremetakis, derives from a reformulation of Fernand Braudel's notion of the historical unconscious and Ernst Bloch's and Walter Benjamin's insights concerning the political significance of the relations between technology, perception, the everyday, and the sensorium (Seremetakis 1994, p. 24). She uses their work as the basis to explore the historical as a sensory dimension in which cultural artifacts considered useless and discarded by a utilitarian and functional modernity, and imposed through colonial and postcolonial annulment of other modes of historical memory and practice, come to constitute a vast social unconscious of sensory-emotive experience that potentially offers up counternarratives of once-valued lifeworlds (1994, pp. 1-17). For Seremetakis, the senses provide an alternate entry point into the history of memory, a site for recovering forgotten or erased experiences that reintegrate the sensorial with the material, contra the fragmentation of the senses proposed by a modernity characterized by the division of the senses and labor and subsumed under the consumerist 
politics of commodification. In this argument, the material artifact is a sensory form in itself and also functions as "meta-sense" (1994, p. 9). Other work on materiality cautions, however, that one must not locate all understandings of the relation between things, perception, knowledge, and being in an epistemology of the senses and proposes the "thing" as ontologically significant (Henare et al. 2007).

\section{THE SENSES SEPARATED}

Among anthropologists who have produced ethnographies of the senses, it is common to find that the reorganization of the sensory domain is entangled with the different materialities of specific sensory practices. Much of this literature is interdisciplinary, engaging anthropologists in dialogue with scholars across the humanities, arts, media studies, and social sciences and theorizing through psychoanalytic, feminist, philosophical, and artistic approaches. In spite of recent calls for a more expansive and integrated conception of the senses, most social and cultural studies of the senses have treated them in relative isolation from one another.

Taste has been foregrounded in various forms of anthropological argument (Mintz 1985, Seremetakis 1994, Stoller 1989). It is framed as a component of symbolic action (Reed-Danahay 1996); as important to the dissemination of ideology and linked through its materiality to politics (Hayes-Conroy \& Hayes-Conroy 2008); as an embodiment of experiences and patterns of migration and displacement (Choo 2004, Highmore 2008) or nationalism (Caldwell 2002); as tied to space and community (Gvion \& Trostler 2008), aesthetics (Jain \& Lochlann 2003), and health (Ferzacca 2004, Guthman 2003); or as embedded in production and consumption (Korsmeyer 2005). Classen et al. (1994) assert taste's equivalence and parallel history to other senses.

The philosophical placement of smell as a lower and elusive sense may account for a lag in its investigation (Curtis 2006). Classen et al. (1994) argue that "smell is cultural," although it possesses a quality of "radical interiority"
(Classen et al. 1994, pp. 3, 5). Corbin (1986) initiated a social, historical, and interpretive approach to odor, fragrance, and the sense of smell. Europe's past has been a primary site of study, with an emphasis on class analysis. Drobnick (2006) provides a succinct history of smell research.

In the west, touch seems to encompass the other senses and has either been debased by its intense corporeality or sublimated in association to feeling and spirituality (Harvey 2003). The corporeality of touch has led to its theorization at the intersection of physical and cultural anthropology (Montagu 1971). Although touch is considered as located primarily in the skin and the hand, the conflation of touch with sensation, feeling, and emotion (Heller-Roazen 2007) leads to a western understanding of touch as a ubiquitous sense. The anthropology of healing and medical diagnosis (Desjarlais 1992, Kuriyama 1999), of life and death (Desjarlais 2003), and of the body (Lock 1995, Lock \& Farquhar 2007) has productively explored touch. Its relation to other senses has been frequently noted (Classen 2005, p. 3), and it has been crucial in arguments for the integration of and thinking beyond the five senses (Howes 2009, pp. 22-29).

The proliferation of scholarship on listening in the past two decades has been characterized as an "auditory turn" that explores "the increasing significance of the acoustic as simultaneously a site for analysis, a medium for aesthetic engagement, and a model for theorization" (Drobnick 2004, p. 10). Feld (1982, 1988, 1991, 1996) pioneered the ethnography of listening with his work on Kaluli acoustemology, expanding it into an ethnographically rich and detailed exploration of the significance of listening in different cultural settings (Feld \& Brenneis 2004). Some research has explored how forms of audition mark the divide between the secular and the religious in modernity (Corbin 1998, Schmidt 2000, Taussig 1993). Consideration of the role of audition in various Islamic spiritual practices has been particularly productive owing to the importance of audition in such traditions (Corbin 1958, Corbin \& 
Pearson 1977, During 1989, Hirschkind 2006, Kapchan 2007, Shannon 2003). Finally, hearing has been treated historically (Erlmann 2004; Samuels et al. 2010, this volume; Sterne 2003; Szendy 2009).

Hearing is often articulated not as a separate sense but as one part of the multisensorial dimensionality of ritual performances (Howes 2005, Leavitt \& Hart 1990, Stoller 1997). Ethnographies that explore local distinctions among the natural, human, and spiritual worlds note that the transformation between worlds often occurs through acts of listening to songs, sounds, and noises (Descola 1994, Lévi-Strauss 1969, Seeger 1987, Stoller 1997, Taussig 1993, Viveiros de Castro 1992). Work on politics of the production of recorded sound has addressed listening as a cultural practice, in the auditory practices of recording studio engineers (Meintjes 2003, Porcello 2005), through the sampling and creation of hiphop beats (Schloss 2004), and via explorations of timbre or noise through the electronic manipulation of sound (Fales 2005, Larkin 2008). Ethnomusicological studies of the politics of musical "identities" (Wong 2004) and musical genres (Novak 2008) address the culture of listening.

No sense has been more thoroughly interrogated by anthropologists than sight. Visual anthropology has a more explicitly elaborated metadiscourse than do anthropologies of the other senses. It is also constructed around, and aware of the plasticity (and textualizing practices) of, its specific presentational mediums: on the one hand, film, photography, video, and digital media (Buckley 2006, Edwards et al. 2006, Pinney \& Peterson 2003); on the other hand, visual artistic mediums such as painting and sculpture (Myers 2001, 2005). Perhaps owing to the disciplinary conversations that led to and followed from the establishment of the Society for Visual Anthropology (El Guindi 2004, pp. 23-49), sight is also the sense that has been least separable from the theorization of its relationship to various mediums of representation. Furthermore, the material means of visual representation became quickly linked to theories of seeing and to technologies of look- ing and of image capture (MacDougall 2006, pp. 240-53; Mead \& Bateson 1977), as well as to concerns in cultural anthropology with modes of textual representation, cultural poetics, and their role in practices of othering, along with a growing interrogation of the colonialist enterprise that underlay much of anthropology's early use of visual media (Edwards 1992, Pinney 1992, Taussig 2009) and an attendant ocularcentrism.

Since the turn of the twenty-first century, many visual anthropologists (Edwards et al. 2006, Grimshaw \& Ravetz 2005, MacDougall 2006, Ruby 2000) have joined in calls from other anthropologists not directly involved in visual anthropology per se (Ingold 2000, Taussig 1993)—many working on sexuality (Kulick 1998, Valentine 2007)_for a more sensorially embodied and integrated ethnography. Pink's (2006) discussion of this move notes that one of the challenges to sensorial ethnography is that "sensory workshops or performance anthropology in which spoken, visual, olfactory and tactile experiences [could be] incorporated" do not "fall within the tradition of creating anthropological publications we disseminate in the form of film or writing" (p. 58). Her suggestion is to explore further "how writing and video might combine to represent sensory experience theoretically and ethnographically" (p. 58). Pink's solution undermines the critique of ocularcentrism implicit in many calls for a multisensory anthropology; it is the very visuality of text and image that stands in for and recovers perceptions not available to the eye.

\section{INTEGRATING THE SENSES}

Leavitt \& Hart (1990) argue against particular forms of sensory determinism that they perceive in studies growing out of McLuhan and Ong, a determinism also found, they suggest, in Febvre (1942), who proposes that the Middle Ages were more acoustic, whereas modernity is more visual. Moreover, not only do McLuhan and Ong insist on finding examples of senses that are supposedly privileged across different cultures or historical periods, but they also tend 
to describe the senses a priori when proposing, for example, that vision is abstract and distant, whereas hearing is comparatively concrete and emotional, without considering either neurobiological findings or specific understandings and uses of the senses in different cultures.

Against such reductionism in the relations between senses and communication and technology, Leavitt \& Hart (1990) propose reclaiming the creative ambiguity of the term aesthetics (from the Greek aisthesis, which means simultaneously sensation, senses, and beauty), through an "ethno-aesthetics that would involve both a study of the senses in their cultural context, and of sensorial prolongations and elaborations operating in the arts" (p. 83, translated by AMO). They argue that because all societies engage with the senses at both a technological and an artistic level, the aesthetic is a privileged site for understanding specific cultural tendencies in the understanding and uses of the senses. The aesthetic elaboration and prolongation of the senses thus provide access to myths, rituals, and ultimately a way of entering into contact with the world of the sacred. Leavitt \& Hart (1990) present "the prodigious aesthetic elaboration of certain sensorial practices" (p. 85, translated by AMO) as a means of communication with the divine in different ritual practices in North India, contrasting different aesthetic (pictorial and sung) and ritual practices of men and women. Finally, ethnoaesthetic studies provide the means of integrating semantics, ritual, and a multisensorial approach to a study of the senses that explores the specific and complementary use of each sense.

The overt politics of many earlier ethnographies of the senses (Feld 1982 [1990]; Howes 1991), as well as some historicizing work (Classen 1993, Curtis 2006), gravitated toward a critique of ocularcentrism. This critique illuminated the dominance of the eye as an idea specific to Enlightenment philosophy, rather than as a fact of modernity, or as empirically grounded in the social world or in physiological experience. Successive work was less concerned with this critique, instead refining understandings of the everyday practice of the senses. Here the sensorium is represented as a world of affect, spirituality, ways of knowing, and sensory interplay situated in a fractured political world.

The earlier sensory ethnographies act as a bridge from the layeredness of Turnerian and Lévi-Straussian interpretations of ritual, performance, and symbol to this growing literature that refines the idea of the multisensory (Feld 1996, Howes 2003; and see below). "Multisensory" here evokes different points of apprehension, interpretation, knowledge construction, and memory making in relation to the world but does not imply their integration under one symbolic dimension. As such, "synaesthesia" need not necessarily entail a conflation of the experience of the senses to a point beyond recognition of their differences. Rather, dynamic cross-relationships are mediated by discursive codes and a plurality of receptivity within a culture (Stroeken 2008).

Contemporary sense ethnographies also benefit from three anthropologists who pushed multisensoriality in new political directions. Taussig (1993) brought dimensions of power, technology, and postcolonial studies together with an argument for the primacy of the senses in formations of knowledge and experience. Csordas (1994a,b, 1997) conjoined practice theory and phenomenology in his exploration of heightened bodily experiences and charismatic healing. Jackson $(1989,1996)$ brought the emotions and phenomenal experience into contact with the senses. His later focus on encounter, networks of relationships, movement, and living with contradictions presents multisensoriality as not only an embodied concept, but also gestural, agentive (Herzfeld 2001), transient, partial, and full of contradictions (2004, 2007, 2009).

Within this new theoretical terrain, scholars have carved out space for gender (Geurts 2002, Sanders 2008); extraordinary experience (Straight 2007); sensory cosmopolitanisms (Farquhar \& Zhang 2005); refigurations of the nature/culture divide (Viveiros de Castro 1992) and of the interactive human and spirit ontology (Parkin 2007); various forms of synaesthetic experience (Meneley 2008); the 
social production of heightened mind-body awareness (Chau 2008); healing, diagnosis, and well-being (Desjarlais 2003, Farquhar 2002, Kuriyama 1999, Stroeken 2008); and truth-making in ethnographic encounters (Straight 2007, West 2007). The multisensory becomes a primary means of understanding conflict and suffering, not as a social aberration as in Turner's model but as a component of lives lived in struggle in relation to a fractured globalized political economy (Frykman et al. 1998, Herzfeld 2001). Contradiction and movement become productive of personhood and sociality rather than being exclusive or in opposition to their constitution. Working in the legacy of Foucault, contemporary multisensorial anthropology seeks to sensorialize Foucauldian ideas about politics. In turn, body politics and sexuality, knowledge archives, surveillance and discipline, and biopower become implicated in sensory experience.

Other calls for a multisensorial scholarship have arisen outside of anthropology, most notably from the study of digital media technologies and its examination of technologically mediated individual and collective experiences. Much of this work argues that the sensorium becomes fully constituted only in its contact with forms of mediation and simultaneously critiques vestiges of media determinism that characterized much early theorization of media, stretching as far back as the work of Benjamin (2008) and Horkheimer \& Adorno (1976). Since the 1990s, digital media studies has centrally considered the ways in which mediums and perceptions are linked. Scholars investigate this linkage in relation to interfaces of artists and audiences and the technologies that produce and constitute contemporary media-based arts. One finds a concern with examining "the sensual," often framed in terms of "sensation" and "sensuality" (Massumi 2002), which Jones (2006) and Munster (2006) explicitly treat as a residue of modernism's segmentation, bureaucratization, and sterilization of the body in the twentieth-century plastic arts (especially painting and sculpture). They wonder about the potentials that exist for tech- nological mediation to reinsert the body into art. What might a techno-embodied art mean for a politics of the senses, for example (Munster 2006)? Media theorists also recognize the potential that new media technologies carry to destabilize presumptions of ocularcentrism, as modes of interaction with media increasingly rely on body, voice, hand, or other bodyand-sense interfaces (Hansen 2006). Embodied knowledge — of technologies and of the self that technologies reveal and produce-prompts a scholarly inquiry into the fully integrated sensorium (Jones 2006, p. 8). Deleuze \& Guattari's concept of the haptic (1987) has gained particular traction in this work (e.g., Marks 2002) as a way to enfold touch and kinesthetics into encounters with images. Especially in analyses of virtual reality, the visual is treated as inseparable from tactile, kinesthetic, and proprioceptive dimensions of mediated encounters and objects (Fisher 1997).

Cinema studies, psychoanalytically influenced literary theory, and art criticism are the immediate antecedents of much new media theory that engages with the senses and embodiment. Within this work, laudable attention is given to the materiality and specificity of media and how objects and their production and consumption are inseparable from them. Delving down to contrast ratios and pixel density, for example, Marks (2002) argues that video is more likely to evoke a "haptic visuality" than an "optic visuality" (pp. 2-3) because, in comparison to film's greater contrast ratio and 20fold greater detail, video is less able to render the detail of human vision. Engaging at this level of materiality, Marks argues, one is pulled away from symbolic-and therefore contested-understandings of the object into a more immediate, and therefore less contested, experience of its particularities.

However, the technological determinism lurking in this analysis is where the correctives of anthropology are especially valuable. Murray \& Sixsmith (1999), in their examination of the nature of embodied experience in virtual reality, are quick to remind readers that "people bring their everyday, real-world understandings and 
social experiences to new virtual encounters" (p. 320). The universalizing "we" that permeates much of new media theory presupposes that individuals bring no culture, no social positioning, and no skill differences to encounters with new media. A more fully developed cyberanthropology that considers, for example, how avatars allow for the adoption of new identitysurfaces even as people bring their deeper and more corporeally embodied social identities to them (Boellstorff 2008), and that foregrounds an ethnographic accountability to how social positioning intersects with the senses, sensations, and sensualities of new media makes a critical contribution to this burgeoning media studies literature.

\section{INTEGRATING DISCOURSE INTO THE STUDY OF THE SENSES}

Myerhoff (2009 [1978]), writing about the Huichol Indians' peyote hunt, argues,

one of the recurring explanations of the power of drugs is their ability to loosen cognitive social categories. Conceptualizations are socially provided and given in language. One of the sources of wonder and ecstasy in the mystic experience is the direct perception of the world, without the intervention and precedence of language and interpretation. The mystic experience is nonverbal precisely because it takes one back behind the word, or more accurately, before the word, to the stunning immediacy of sense data. (p. 305)

Meyerhoff's opposition between language and the senses is reprinted in Howes's The Sixth Sense Reader (2009). In the introduction, Howes stresses that the idea of five specific, discrete senses is culturally and historically determined, not a biological fact. He argues for replacing the term "senses" with "sensorium," a term that "straddles the divide between mind and body, cognition and sensation" (p. 1) and speculates that it is reasonable to ask whether, "in lieu of language, animals_ or certain species—have developed extrasensory modalities for staying in touch with each other" (p. 12). After describing Aristotle's model of sentience by stating that "sensation takes the form of 'a kind of mean' between two extremes .... sight between white and black, hearing between shrill and dull, and so on ...," Howes inserts a footnote that, while acknowledging the Saussurean notion of différence behind this phraseology, reads, "I would be the last to suggest we import a linguistic model into studies of how the senses function" (p. 39). These passages are indicative of the uncomfortable space occupied by the study of language, speech, and discourse in much research about the senses.

Arguably, a recurring feature in the anthropology of the senses is its rejection of language, discourse, and semiotics as modes for encountering and understanding the sensuous cultural world [notable exceptions include Classen's (1993) chapter on words and metaphoric terminology; Stoller's (1997) recognition of the significance of listening to the words of Songhay griots; as well as Csordas (1994c, 1997), Engelke (2007), and Geurts (2002)]. Recall, for example, Howes's distrust of the "antisensual" nature of anthropology's turn to "discourse" (2005) and "the detour represented by the rise of the textual model of cultural analysis in the 1970s" (2003). Similarly, Seremetakis (1994) posits clear differences between the construction of meaning and truth through sensorial experience and that constructed through language. The relation between the body and things "points to the perceptual construction of truth as an involuntary disclosure of meaning through the senses" (p. 6) so that truth is "extralinguistic and revealed through expression, performance, material culture and conditions of embodiment" (p. 6). Seremetakis, however, affirms that the history of the senses can be uncovered through contact with people via "fairy tales, anecdotes, folklore, and myth" (p. 9). As such, her work demonstrates an ambiguity between the narration of the senses through performative and historicizing linguistic genres and a critique of language as the sole repository of truth and meaning. 
On a broader level, the opposition between language and body in much work on the senses derives from a critique of western epistemologies that locates thinking as a logo-centric activity based on the semantic content of words, in which the idea of (rational) thought is based on a separation between culture and nature, between man as the observer, and nature or the universe as the observed. Latour (1993) refers to this process of separation of an object and a knowing subject from its surroundings as "epistemologies of purification." In Latour's epistemologies, the object is made amenable to knowledge constructions, while the knower as an articulator of power relations is enacted through such knowledge practices. The anthropology of the senses positions itself as speaking back to such purificatory practices by reinserting sensorial perception as a site of knowledge construction. It often does so, however, through a critique of textcentered approaches to culture and language as the privileged site for the (de)construction of knowledge. Although we agree with the general critique of such purificatory practices and the inclusion of the body proposed by the anthropology of the senses, we argue that centering a return to the senses on an opposition between text-centered approaches to culture and bodycentered approaches to culture neglects broad areas of overlap and agreement between various approaches to the embodied sensuous nature of human experience and sociability. Much recent work on language and discourse has similarly rejected a mentalist framing of language, strongly emphasizing its sensuous and sociable properties.

The three genealogies we identified above for work on the senses have strong traction in linguistics and linguistic anthropology as well. The life of discourse is physical, material, and emotional as well as intellectual. Communication is a multisensory experience, including not only the ears and eyes, but all sensory apparati. Speech is not simply the manifestation of thoughts to be transferred from the head of one individual into the head of another (although it may indeed serve that communicative purpose), but is rather the acoustic signature of the whole person (Truax 2001), including embodied and sensory markers of emotional state (Lutz \& Abu-Lughod 1990, Ochs \& Schieffelin 1989), age (Eckert 1998), social class (Fox 2004), geographic region (Wolfram \& Schilling-Estes 2005), and gender identification (Bucholz et al. 1999). Far from a secondary ratiocination of experience, language and discourse exist as key components of experience in the unfolding of everyday life. [Schutz's (1982) discussion of Kurt Goldstein's theory of aphasia and experience shows this to be the case.] The link between sensory experience and language is not limited to lexical categorization. Grammatical, morpho-syntactic, intonation contour, metrical, generic, gesture and bodily hexis, and other sensory organizational aspects of discourse are all orchestrated for the purposes of presenting multilayered messages to the senses.

Nor is language simply an encoding of rational thought transferred from mind to mouth. It is produced physically, by lungs, diaphragm, lips, teeth, tongue, and glottis, fully embodied in its manifestation of physical presence (Perkell 1997, Stone et al. 2003). Phonologists and phoneticians have developed sophisticated methods for describing the precise physical aspects of vocal production and proprioception that result in particular utterances (Bolinger 1986, Sundberg \& Thalen 2001). But the description is not limited to a scientific or biological discourse. Here we return to Pink's (2006) call for performance ethnography because performance ethnographers are surely aware of the embodied and material aspects that bring discourse and language to sensory presence.

It seems to us that much of the anthropology of the senses confuses two notions of discourse. As expressed by Bauman \& Briggs (1992) with respect to linguistic anthropology, "highly divergent conceptualizations of the nature and significance of 'discourse' have often widened the gap between research agendas" (p. 159). Bauman \& Briggs are referring to a confusion 
between a discourse-centered approach to culture (Sherzer 1987, Urban 1991, Woodbury 1992) and a Foucauldian poststructuralist approach to discourse. The former, with its careful attention to language use, treats language as "formal and functional patterning and dimensions of social interaction, social structure and cultural processes" (Bauman \& Briggs 1992, p. 160). The Foucauldian poststructuralist approach is concerned with the deconstruction of social power rather than with paying specific attention to the details of expressive culture events. The anthropological discourse-centered approaches to culture have yielded sophisticated analyses of aesthetic aspects of expressive culture that can be intertwined with sensorial modes of knowing and embodied expressive-sensorial practices (Basso 1985, Feld 1996, Fox 2004, Kapchan 2007, Meintjes 2004, Novak 2008, Porcello 1998, Samuels 2004). Furthermore, the deconstruction of discourses of the body (Foucault 1988-1990, Lock \& Farquhar 2007), of the sensorial practices of colonialism (Seremetakis 1994, Taussig 1993), of the politics of media circulation (Meintjes 2003), and of the notion of personhood (Descola 1994, Desjarlais 1992, Geurts 2002, Straight 2007) have been foundational for enabling us to think about the senses. It is more productive to treat discourse as part and parcel of processes of embodiment and knowledge and sense-making, rather than to dichotomize bodily sensorial knowledge and linguistic expression.

In conclusion, as the multisensory nature of embodied experience is increasingly recognized, the supremacy of sight as the historical articulator of modernity is increasingly challenged by an anthropology of the senses. We wish to emphasize the existence of productive synergies among scholars working in the anthropology of the senses, those researching mediated sensorial experiences in the arts and cinema studies, and linguistic anthropologists who examine language as an embodied expressive practice. Some scholars call for an integrative approach to the anthropology of the senses that attends to aesthetics (Leavitt \& Hart 1990, Herzfeld 2001, Howes 2009). However, close formal analysis of expressive forms has increasingly incorporated body-sensorial knowledge. We suggest a complementary detailed attention to expressive forms across cultures-including discourse, new media arts, and cinema-and multisensory ethnography. Transdisciplinary ethnographic studies of the senses are ideal sites in which to question the relationship among artifacts, technologies, personhood, and the body, enabling an understanding of the senses not only as a means of knowing the world, but also as an ontological object of anthropological study. Such an approach acknowledges the importance of the senses in the postcolonial rethinking of modernity.

\section{DISCLOSURE STATEMENT}

The authors are not aware of any affiliations, memberships, funding, or financial holdings that might be perceived as affecting the objectivity of this review.

\section{ACKNOWLEDGMENTS}

The authors thank Debborah Battaglia, Richard Bauman, Steven Feld, and Susan Lepselter for reading various iterations of this article, as well as Alessandra Ciucci, for research support, and Sowmya Krishnamoorthy, a conversational partner throughout much of this article's preparation.

\section{LITERATURE CITED}

Basso EB. 1985. A Musical View of the Universe: Kalapalo Myth and Ritual Performances. Philadelphia: Univ. Penn. Press

Bauman R. 1977. Verbal Art as Performance. Long Grove, IL: Waveland 
Bauman R, Briggs CL. 1992. Genre, intertextuality, and social power. F. Ling. Anthropol. 2(2):131-72

Benjamin W. 2008 [1935-1936]. The work of art in the age of its technological reproducibility (second version). In The Work of Art in the Age of its Technological Reproducibility and Other Writings on Media, ed. MW Jennings, TY Levin, B Doherty, pp. 19-55. Cambridge, MA: Harvard Univ. Press

Boas F. 1901. The mind of primitive man. F. Am. Folk. 14(52):1-11

Boellstorff T. 2008. Coming of Age in Second Life: An Antbropologist Explores the Virtually Human. Princeton, NJ: Princeton Univ. Press

Bolinger D. 1986. Intonation and its Parts: Melody in Spoken English. Stanford, CA: Stanford Univ. Press

Bucholz M, Liang AC, Sutton L. 1999. Reinventing Identities: The Gendered Self in Discourse. New York: Oxford Univ. Press

Buckley L. 2006. Studio photography and the aesthetics of citizenship in The Gambia, West Africa. See Edwards et al. 2006, pp. 61-85

Caldwell ML. 2002. The taste of nationalism: food politcs in postsocialist Moscow. Etbnos 67(3):295-319

Carpenter ES. 1973. Eskimo Realities. New York: Holt, Rinehart and Winston

Chau AY. 2008. The sensorial production of the social. Ethnos 73(4):485-504

Choo S. 2004. Eating satay babi: sensory perception of transnational movement. F. Intercult. Stud. 25(3):203-13

Classen C. 1993. Worlds of Sense: Exploring the Senses in History and Across Cultures. London: Routledge

Classen C. 1997. Foundations for an anthropology of the senses. Int. Soc. Sci. 7. 153:401-12

Classen C. 2005. The Book of Touch. Oxford/New York: Berg

Classen C, Howes D, Synnott A. 1994. Aroma: The Cultural History of Smell. New York: Routledge

Corbin A. 1986. The Foul and the Fragrant: Odor and the French Social Imagination, transl. M Kochan, R Porter, C Prendergast. Cambridge, MA: Harvard Univ. Press

Corbin A. 1998. Village Bells: Sound and Meaning in the Nineteenth Century French Countryside. New York: Columbia Univ. Press

Corbin H. 1958. Imagination Créatrice dans le Soufisme d'Ibn 'Arabi. Paris: Flammarion

Corbin H, Pearson N. 1977. Spiritual Body and Celestial Earth: From Mazden Iran to Shi'ite Iran. Princeton, NJ: Princeton Univ. Press

Crapanzano V. 1992. Hermes' Dilemma and Hamlet's Desire: On the Epistemology of Interpretation. Cambridge, MA: Harvard Univ. Press

Csordas TJ, ed. 1994a. Embodiment and Experience: The Existential Ground of Culture and Self. Cambridge, UK: Cambridge Univ. Press

Csordas TJ. 1994b. The Sacred Self: A Cultural Phenomenology of Charismatic Healing. Berkeley: Univ. Calif. Press

Csordas TJ. 1994c. Words from the Holy People: a case study in cultural phenomenology. See Csordas 1994a, pp. $269-90$

Csordas TJ. 1997. Language, Charisma, and Creativity: The Ritual Life of a Religious Movement. Berkeley: Univ. Calif. Press

Curtis B. 2006. "I can tell by the way you smell": dietetics, smell, social theory. Senses Soc. 3(1):5-22

Deleuze G, Guattari F. 1987. A Thousand Plateaus: Capitalism and Schizophrenia, transl. B Massumi. Minneapolis: Univ. Minn. Press

Descola P. 1994. In the Society of Nature: A Native Ecology in Amazonia. Cambridge, UK/New York: Cambridge Univ. Press

Desjarlais RR. 1992. Sensory Biographies: Lives and Deaths among Nepal's Yolmo Buddhists. Berkeley: Univ. Calif. Press

Desjarlais RR. 2003. Body and Emotion: The Aesthetics of Healing in the Nepali Himalayas. Philadelphia: Univ. Penn. Press

Drobnick J. 2004. Listening awry. In Aural Cultures, ed. J Drobnick, pp. 9-18. Toronto: YYZ Books

Drobnick J, ed. 2006. The Smell Culture Reader. Oxford/New York: Berg

During J. 1989. Musique et Mystique dans les Traditions de l'Iran. Paris: Inst. Fr. Rech. Iran/Diffusion, Ed. Peters

Eckert P. 1998. Age as a sociolinguistic variable. In The Handbook of Sociolinguistics, ed. F Coulmas, pp. 151-67. London: Blackwell

Edwards E. 1992. Anthropology and Photography 1860-1920. New Haven/London: Yale Univ. Press 
Edwards E, Gosden C, Phillips RB, eds. 2006. Sensible Objects: Colonialism, Museums and Material Culture. Oxford: Berg

El Guindi F. 2004. Visual Anthropology: Essential Method and Theory. New York: Alta Mira

Engelke M. 2007. A Problem of Presence: Beyond Scripture in an African church. Berkeley: Univ. Calif. Press

Erlmann V. 2004. But what of the ethnographic ear? Anthropology, sound and the senses. In Hearing Cultures: Essays on Sound, Listening and Modernity, ed. V Erlmann, pp. 1-20. Oxford/New York: Berg

Fales C. 2005. Short-circuiting perceptual systems: timbre in ambient and techno music. See Greene \& Porcello 2005, pp. 156-80

Farquhar J. 2002. Appetites: Food and Sex in Postsocialist China. Durham, NC: Duke Univ. Press

Farquhar J, Zhang Q. 2005. Biopolitical Beijing: pleasure, sovereignty and self-cultivation in China's capital. Cult. Anthropol. 20(3):303-27

Febvre L. 1942. Le Probleme de l'incroyance au XVIe siecle. La religión de Rabelais. Paris: Albin Michel

Feld S. 1988. Aesthetics as iconicity of style, or 'lift-up-oversounding': getting into the Kaluli groove. $Y r$. Trad. Mus. 20:74-113

Feld S. 1990 [1982]. Sound and Sentiment: Birds, Weeping, Poetics, and Song in Kaluli Expression. Philadelphia: Univ. Penn. Press

Feld S. 1991. Sound as a symbolic system: the Kaluli drum. See Howes 1991, pp. 79-99

Feld S. 1996. Waterfalls of song: an acoustemology of place resounding in Bosavi, Papua New Guinea. In Senses of Place, ed. S Feld, KH Basso, pp. 91-136. Santa Fe, NM: Sch. Am. Res. Press

Feld S, Brenneis D. 2004. Doing anthropology in sound. Am. Ethnol. 31(4):461-74

Ferzacca S. 2004. Lived food and judgments of taste at a time of disease. Med. Anthropol. 23:41-67

Fisher J. 1997. Relational sense: toward a haptic aesthetics. Paracbute 87:4-11

Foucault M. 1988-1990. History of Sexuality. New York: Vintage

Fox AA. 2004. Real Country: Music and Language in Working-Class Culture. Durham, NC: Duke Univ. Press

Frykman J, Seremetakis N, Ewert S, eds. 1998. Identities in Pain. Lund, Swed.: Nordic Acad. Press

Geurts KL. 2002. Culture and the Senses: Embodiment, Identity, and Well-Being in an African Community. Berkeley: Univ. Calif. Press

Goody J. 1977. The Domestication of the Savage Mind. Cambridge, UK: Cambridge Univ. Press

Greene PD, Porcello T, eds. 2005. Wired for Sound: Engineering and Technologies in Sonic Cultures. Middletown, CT: Wesleyan Univ. Press

Grimshaw A, Ravetz A, eds. 2005. Visualizing Antbropology. Bristol, UK: Intellect

Guthman J. 2003. Fast food/organic food: reflexive tastes and the making of 'yuppie chow.' Soc. Cult. Geogr. $4(1): 45-58$

Gvion L, Trostler N. 2008. From spaghetti and meatballs through Hawaiian pizza to sushi: the changing nature of ethnicity in American restaurants. F. Pop. Cult. 41(6):950-74

Hansen MBN. 2006. Bodies in Code: Interfaces with Digital Media. New York: Routledge

Harvey ED. 2003. Sensible Flesh: On Touch in Early Modern Culture. Philadelphia: Univ. Penn. Press

Hayes-Conroy A, Hayes-Conroy J. 2008. Taking back taste: feminism, food and visceral politics. Gender Place Cult. 15(5):461-73

Heller-Roazen D. 2007. Inner Touch: Archaeology of a Sensation. New York: Zone

Henare A, Holbraa M, Wastell S. 2007. Thinking through Things, Theorising Artifacts Ethnographically. London: Routledge

Herzfeld M. 2001. Anthropology: Theoretical Practice in Culture and Society. Oxford: Blackwell

Highmore B. 2008. Alimentary gents: food, cultural theory and multiculturalism. F. Intercult. Stud. 29(4):38198

Hirschkind C. 2006. The Ethical Soundscape: Cassette Sermons and Islamic Counterpublics. New York: Columbia Univ. Press

Horkheimer M, Adorno TW. 1976. The Culture Industry: Enligbtenment as Mass Deception. New York: Continuum Int.

Howes D, ed. 1990. Les <<cinq >> sens. Anthropolog. Soc. 14(2):Spec. issue

Howes D, ed. 1991. Varieties of Sensory Experience: A Sourcebook in the Anthropology of the Senses. Toronto/Buffalo: Univ. Tor. Press 
Howes D. 2003. Sensual Relations: Engaging the Senses in Culture and Social Theory. Ann Arbor: Univ. Mich. Press

Howes D. 2005. Empire of the Senses: The Sensual Culture Reader. Oxford/New York: Berg

Howes D, ed. 2009. The Sixth Sense Reader. Oxford: Berg

Ingold T. 2000. The Perception of the Environment: Essays in Livelibood, Dwelling, and Skill. London: Routledge

Jackson M. 1989. Paths Toward a Clearing: Radical Empiricism and Ethnographic Enquiry. Bloomington: Ind. Univ. Press

Jackson M, ed. 1996. Things as They Are: New Directions in Phenomenological Anthropology. Bloomington: Ind. Univ. Press

Jackson M. 2004. In Sierra Leone. Durham, NC: Duke Univ. Press

Jackson M. 2007. Excursions. Durham, NC: Duke Univ. Press

Jackson M. 2009. The Palm at the End of the Mind: Relatedness, Religiosity and the Real. Durham, NC: Duke Univ. Press

Jain S, Lochlann S. 2003. "Come up to the Kool taste": African American upward mobility and the semiotics of smoking menthols. Public Cult. 15(2):295-322

Jay M. 1993. Downcast Eyes: The Denigration of Vision in Twentieth Century French Thought. Berkeley: Univ. Calif. Press

Jones C, ed. 2006. Sensorium: Embodied Experience, Technology, and Contemporary Art. Cambridge, MA: MIT Press

Kapchan DA. 2007. Traveling Spirit Masters: Moroccan Gnawa Trance and Music in the Global Marketplace. Middletown, CT: Wesleyan Univ. Press

Korsmeyer C, ed. 2005. The Taste Culture Reader: Experiencing Food and Drink. Oxford/New York: Berg

Kulick D. 1998. Travesti: Sex, Gender, and Culture Among Brazilian Transgendered Prostitutes. Chicago: Univ. Chicago Press

Kuriyama S. 1999. Expressiveness of the Body and the Divergence of Greek and Chinese Medicine. New York: Zone

Lambek M. 2003. The Weight of the Past: Living with History in Mahajanga, Madagascar. New York: Palgrave Macmillan

Lambek M, Strathern A, eds. 1998. Bodies and Persons: Comparative Perspectives from Africa and Melanesia. Cambridge, UK: Univ. Cambridge Press

Larkin B. 2008. Signal and Noise: Media, Infrastructure and Urban Culture in Nigeria. Durham, NC/London: Duke Univ. Press

Latour B. 1993. We Have Never Been Modern. New York/London: Harvester, Wheatsheaf

Leavitt J, Hart LM. 1990. Critique de la 'raison' sensorielle, l'élaboration esthétique des senses dans une société himalayenne. Antbropol. Soc. 14(2):77-98

Lévi-Strauss C. 1969. The Raw and the Cooked. New York: Harper and Row

Lock M. 1995. Encounters with Aging: Mythologies of Menopause in Japan and North America. Berkeley: Univ. Calif. Press

Lock M, Farquhar J. 2007. Beyond the Body Proper: Reading the Anthropology of Material Life. Durham, NC/London: Duke Univ. Press

Lutz CA, Abu-Lughod L, eds. 1990. Language and the Politics of Emotion. Cambridge, UK: Cambridge Univ. Press

Marks LU. 2002. Touch: Sensuous Theory and Multisensory Media. Minneapolis: Univ. Minn. Press

Marx K. 1988 [1844]. Private property and communism. In The Economic and Philosophic Manuscripts of 1844 of Karl Marx, transl. M Millgan, pp. 99-114. Amherst, NY: Prometheus

Massumi B. 2002. Parables for the Virtual: Movement, Affect, Sensation. Durham, NC: Duke Univ. Press

McDougall D. 2006. The Corporeal Image: Film, Ethnography and the Senses. Princeton, NJ: Princeton Univ. Press

Mead M, Bateson G. 1977. Margaret Mead and Gregory Bateson on the use of the camera in anthropology. Stud. Antbropol. Vis. Cult. 4(2):78-80

Meintjes L. 2003. Making Music Zulu in a South African Studio. Durham, NC/London: Duke Univ. Press

Meintjes L. 2004. Shoot the sergeant, shatter the mountain: the production of masculinity in Zulu ngoma song and dance in postapartheid South Africa. Ethnomusicol. Forum 13(3):173-201 
Meneley A. 2008. Oleo-signs and quali-signs: the qualities of olive oil. Ethnos 73(3):303-26

Mintz SW. 1985. Sweetness and Power. The Place of Sugar in Modern History. London: Penguin

Montagu A. 1971. Touching: The Human Significance of the Skin. New York: Columbia Univ. Press

Munster A. 2006. Materializing New Media: Embodiment in Information Aesthetics. Hanover, NH: Dartmouth Coll. Press

Murray C, Sixsmith J. 1999. The corporeal body in virtual reality. Ethos 27(3):315-43

Myerhoff B. 2009 [1978]. Peyote and the mystic vision. See Howes 2009, pp. 297-310

Myers F, ed. 2001. The Empire of Things. Santa Fe, NM: Sch. Am. Res.

Myers F. 2005. 'Primitivism', anthropology, and the category of 'primitive art'. In Handbook of Material Culture, ed. C Tilly, W Keane, S Küchler, M Rowlands, P Spyer, pp. 267-84. London: Sage

Novak D. 2008. $2.5 \times 6$ meters of space: Japanese music coffeehouses and experimental practices of listening. Pop. Music 27(1):15-34

Ochs E, Schieffelin B. 1989. Language has a heart. Text 99(1):7-25

Parkin D. 2007. Wafting on the wind: smell and the cycle of spirit and matter. 7. R. Anthropol. Inst. pp. S39-53

Perkell J. 1997. Articulatory processes. In The Handbook of Phonetic Sciences, ed. W Hardcastle, J Laver, pp. 333 70. Malden, MA: Blackwell

Pink S. 2006. The Future of Visual Anthropology: Engaging the Senses. New York: Routledge

Pinney C. 1992. The parallel histories of anthropology and photography. See Edwards 1992, pp. 74-95

Pinney C, Peterson N, eds. 2003. Photogaphy's Other Histories. Durham, NC: Duke Univ. Press

Porcello T. 1998. Tails out: social phenomenology and the ethnographic representation of technology in music making. Ethnomusicology 42(3):485-510

Porcello T. 2005. Music mediated as live in Austin: sound, technology and recording practice. See Greene \& Porcello 2005, pp. 103-17

Reed-Danahay D. 1996. Champagne and chocolate: "taste" and inversion in a French wedding ritual. Am. Anthropol. 98(4):750-61

Ruby J. 2000. Picturing Culture. Chicago: Univ. Chicago Press

Samuels D. 2004. Putting a Song on Top of It: Expression and Identity on the San Carlos Apache Reservation. Tucson: Univ. Ariz. Press

Samuels DW, Porcello T, Meintjes L, Ochoa AM. 2010. Soundscapes: toward a sounded anthropology. Annu. Rev. Anthropol. 39:329-45

Sanders T. 2008. Beyond Bodies: Rainmaking and Sense Making in Tanzania. Toronto: Univ. Tor. Press

Schloss JG. 2004. Making Beats, The Art of Sample-Based Hip Hop. Middletown, CT: Wesleyan Univ. Press

Schmidt LE. 2000. Hearing Things: Religion, Illusion and the American Enlightenment. Cambridge, MA: Harvard Univ. Press

Schutz A. 1982. Language, language disturbances, and the texture of consciousness. In Collected Papers I: The Problem of Social Reality, ed. M Natanson. pp. 260-86. Hingham, MA: Kluwer

Seeger A. 1987. Why Suya Sing. A Musical Anthropology of an Amazonian People. Cambridge, UK: Cambridge Univ. Press

Seremetakis NC. 1994. Perception and Memory as Material Culture in Modernity. Boulder, CO: Westview

Shannon J. 2003. Emotion, performance, and temporality in Arab music: reflections on Tarab. Cult. Anthropol. 18(1):72-98

Sherzer J. 1987. A discourse-centered approach to language and culture. Am. Anthropol. 89:295-309

Sterne J. 2003. The Audible Past: Cultural Origins of Sound Reproduction. Durham, NC: Duke Univ. Press

Stoller P. 1989. Taste of Ethnographic Things: The Senses in Anthropology. Philadelphia: Univ. Penn. Press

Stoller P. 1997. Sensuous Scholarship. Philadelphia: Univ. Penn. Press

Stone RE, Cleveland T, Sundberg J, Prokop J. 2003. Aerodynamic and acoustical measures of speech, operatic and Broadway styles in a professional female singer. 7. Voice 17:283-98

Straight B. 2007. Miracles and Extraordinary Experience in Northern Kenya. Philadelphia: Univ. Penn. Press

Stroeken K. 2008. Sensory shifts and 'synaesthetics' in Sukuma healing. Ethnos 73(4):466-84

Sundberg J, Thalén M. 2001. Describing different styles of singing: a comparison of a female singer's voice source in "classical," "pop," "jazz" and "blues." Logoped. Phoniatr. Vocol. 26:82-93

Synnott A. 1991. Puzzling over the senses: from Plato to Marx. See Howes 1991, pp. 61-76 
Szendy P. 2009. The auditory return (the point of listening). Presented at Think. Listening Conf., Oct. 2-4, Univ.

Tex., Austin

Taussig M. 1993. Mimesis and Alterity: A Particular History of the Senses. New York: Routledge

Taussig M. 2009. What Color is the Sacred? Chicago: Univ. Chicago Press

Truax B. 2001. Acoustic Communication. Westport: Ablex

Urban G. 1991. A Discourse-Centered Approach to Culture: Native South American Myths and Rituals. Austin: Univ. Tex. Press

Valentine D. 2007. Imagining Transgender: An Ethnography of a Category. Durham, NC: Duke Univ. Press

Viveiros de Castro E. 1992. From the Enemy's Point of View: Humanity and Divinity in an Amazonian Society. Chicago: Univ. Chicago Press

Viveiros de Castro E. 2004. Exchanging perspectives: the transformation of objects into subjects in Amerindian ontologies. Common Knowl. 10(3):463-84

West HG. 2007. Ethnographic Sorcery. Chicago: Univ. Chicago Press

Wolfram W, Schilling-Estes N. 2005 [1991]. American English: Dialects and Variation. Oxford, UK: WileyBlackwell

Wong DA. 2004. Speak it Louder: Asian Americans Making Music. New York: Routledge

Woodbury A. 1992. Prosodic elements and prosodic structures in natural discourse. In Proceedings of the IRCS Workshop on Prosody in Natural Speech. Institute for Research in Cognitive Science Technical Report No. 92-37, ed. M Liberman, C McLemore. pp. 241-53. Philadelphia: Inst. Res. Cogn. Sci., Univ. Penn. 
赵

\section{Contents}

Annual Review of Anthropology

Volume 39, 2010

\section{Prefatory Chapter}

A Life of Research in Biological Anthropology

Geoffrey A. Harrison

\section{Archaeology}

Preindustrial Markets and Marketing: Archaeological Perspectives

Gary M. Feinman and Christopher P. Garraty

Exhibiting Archaeology: Archaeology and Museums

Alex W. Barker

Defining Behavioral Modernity in the Context of Neandertal and Anatomically Modern Human Populations April Nowell

The Southwest School of Landscape Archaeology

Severin Fowles

Archaeology of the Eurasian Steppes and Mongolia

Bryan Hanks.... 469

\section{Biological Anthropology}

Miocene Hominids and the Origins of the African Apes and Humans David R. Begun

Consanguineous Marriage and Human Evolution A.H. Bittles and M.L. Black

Cooperative Breeding and its Significance to the Demographic Success of Humans

Karen L. Kramer

\section{Linguistics and Communicative Practices}

Enactments of Expertise

E. Summerson Carr 
The Semiotics of Brand

Paul Manning

The Commodification of Language

Monica Heller....

Sensory Impairment

Elizabeth Keating and R. Neill Hadder

The Audacity of Affect: Gender, Race, and History in Linguistic

Accounts of Legitimacy and Belonging

Bonnie McElhinny

Soundscapes: Toward a Sounded Anthropology

David W. Samuels, Louise Meintjes, Ana Maria Ochoa, and Thomas Porcello.

Ethnographic Approaches to Digital Media

E. Gabriella Coleman

\section{International Anthropology and Regional Studies}

Peopling of the Pacific: A Holistic Anthropological Perspective

Patrick V. Kirch

Anthropologies of the United States

Fessica R. Cattelino

\section{Sociocultural Anthropology}

The Reorganization of the Sensory World

Thomas Porcello, Louise Meintjes, Ana Maria Ochoa, and David W. Samuels.

The Anthropology of Secularism

Fenella Cannell

Anthropological Perspectives on Structural Adjustment and Public

Health

James Pfeiffer and Rachel Chapman

Food and the Senses

David E. Sutton

The Anthropology of Credit and Debt

Gustav Peebles

Sense and the Senses: Anthropology and the Study of Autism

Olga Solomon

Gender, Militarism, and Peace-Building: Projects of the Postconflict Moment

Mary H. Moran 
Property and Persons: New Forms and Contests in the Era of Neoliberalism

Eric Hirsch . ...

Education, Religion, and Anthropology in Africa

Amy Stambach

The Anthropology of Genetically Modified Crops

Glenn Davis Stone.

Water Sustainability: Anthropological Approaches and Prospects

Ben Orlove and Steven C. Caton

\section{Theme I: Modalities of Capitalism}

The Semiotics of Brand

Paul Manning

The Commodification of Language

Monica Heller

Anthropological Perspectives on Structural Adjustment and Public Health

James Pfeiffer and Rachel Chapman

Preindustrial Markets and Marketing: Archaeological Perspectives

Gary M. Feinman and Christopher P. Garraty

The Anthropology of Credit and Debt

Gustav Peebles

Property and Persons: New Forms and Contests in the Era of Neoliberalism

Eric Hirsch

The Anthropology of Genetically Modified Crops

Glenn Davis Stone.... 381

Theme II: The Anthropology of the Senses

The Reorganization of the Sensory World

Thomas Porcello, Louise Meintjes, Ana Maria Ochoa and David W. Samuels .51

Sensory Impairment

Elizabeth Keating and R. Neill Hadder

Food and the Senses

David E. Sutton

Sense and the Senses: Anthropology and the Study of Autism

Olga Solomon 
Soundscapes: Toward a Sounded Anthropology

David W. Samuels, Louise Meintjes, Ana Maria Ochoa, and Thomas Porcello.....

\section{Indexes}

Cumulative Index of Contributing Authors, Volumes 30-39 .................... 507

Cumulative Index of Chapter Titles, Volume 30-39 ............................. 510

\section{Errata}

An online log of corrections to Annual Review of Antbropology articles may be found at http://anthro.annualreviews.org/errata.shtml 